\title{
Influence of Weeding on the Performance of White Maize Varieties
}

\author{
Shammi Akter ${ }^{*}$, Muhammad Abdul Mannan"1, Tahmina Ahmmed1, Sumayea Khan², \\ Mahrupa Tasnim², Jafar Ullah ${ }^{1}$
}

${ }^{1}$ Department of Agronomy, Sher-e-Bangla Agricultural University, Dhaka, Bangladesh

${ }^{2}$ Department of Genetics and Plant Breeding, Sher-e-Bangla Agricultural University, Dhaka, Bangladesh

Email: *saushammi71@gmail.com

How to cite this paper: Akter, S., Mannan, M.A., Ahmmed, T., Khan, S., Tasnim, M and Ullah, J. (2021) Influence of Weeding on the Performance of White Maize Varieties. American Journal of Plant Sciences, 12, 1011-1022.

https://doi.org/10.4236/ajps.2021.127069

Received: June 3, 2021

Accepted: July 12, 2021

Published: July 15, 2021

Copyright (c) 2021 by author(s) and Scientific Research Publishing Inc. This work is licensed under the Creative Commons Attribution International License (CC BY 4.0).

http://creativecommons.org/licenses/by/4.0/

\begin{abstract}
The experiment was conducted at agronomy farm of Sher-e-Bangla Agricultural University, Dhaka from November 2017 to April 2018 to investigate the influence of weeding regimes on the performance of white maize varieties. The experiment comprised two varieties viz. YANGNUO-3000 and PSC-121, designated as $V_{1}$ and $V_{2}$ respectively combined with four weed control treatments viz. $\mathrm{T}_{0}=$ No weeding, $\mathrm{T}_{1}=$ One hand weeding at $60 \mathrm{DAS}$ (days after sowing), $\mathrm{T}_{2}=$ two hand weeding at $40 \mathrm{DAS}$ and $60 \mathrm{DAS}$ and $\mathrm{T}_{3}=$ Weed free after 40 DAS. The experiment was laid out in RCBD (factorial) with three replications. PSC-121 showed the superior performance in terms of plant height, leaf number plant ${ }^{-1}$, number of grains $\operatorname{cob}^{-1}$ (468.75), 100 grains weight $(35.0837 \mathrm{~g})$, grain yield $\left(8.28 \mathrm{t} \mathrm{ha}^{-1}\right)$, stover yield $\left(6.56 \mathrm{t} \mathrm{ha}^{-1}\right)$ and harvest index (55.58\%) over YANGNUO-3000. In the case of weed control treatments, the highest plant height, leaf number plant ${ }^{-1}$, number of grains $\operatorname{cob}^{-1}$ (464.54), 100 grains weight $(37 \mathrm{~g})$, grain yield $\left(9.25 \mathrm{t} \mathrm{ha}^{-1}\right)$ and stover yield $\left(7.46 \mathrm{t} \mathrm{ha}^{-1}\right)$ were reported from $\mathrm{T}_{3}$. All the parameters studied were found lowest with $\mathrm{T}_{0}$. However, in terms of interaction, no single interaction was superior to other alternatives. But in most of the cases $V_{2} T_{3}$ showed the highest values regarding the maximum plant height, leaf number plant $^{-1}$, number of grains $\mathrm{cob}^{-1}$ (494.97) and 100 grains weight (38 g). $\mathrm{V}_{2} \mathrm{~T}_{3}$ showed the highest grain yield $\left(9.33 \mathrm{t} \mathrm{ha}^{-1}\right)$, whereas, $\mathrm{V}_{1} \mathrm{~T}_{0}$ showed the lowest grain yield $\left(5.49 \mathrm{t} \mathrm{ha}^{-1}\right)$. The lowest weed density and weed biomass $\left(12.17\right.$ no. $\mathrm{m}^{-2}$ and $4.33 \mathrm{~g} \cdot \mathrm{m}^{-2}$ ) was recorded from $\mathrm{T}_{3}$. The highest weed control efficiency (94.38\%) was also recorded from $\mathrm{T}_{3}$. In the case of variety $\mathrm{V}_{2}$ showed better performance in terms of weed density, weed biomass and WCE (46.32\%).
\end{abstract}

\section{Keywords}

White Maize, Hand Weeding, Yield, PSC-121, Hybrid Variety 


\section{Introduction}

Among the cereal crops maize is the third most important one in the world providing a major source of food in many countries. It is mainly grown as fodder and feed. In the industrialized countries, it is used as raw material for manufacturing pharmaceutical and other industrial products [1]. Rice is the major staple food in Bangladesh but globally the yield growth of rice has become either stagnated or slowed down [2]. At present, agricultural land is shrinking due to urbanization, industrialization and infrastructure development but the demand for food is increasing with growing population and rising income. Introduction of white maize in Bangladesh as human food can be a viable alternative for sustaining food security given the productivity of maize much higher than rice and wheat [3]. Maize is a comparatively new crop in Bangladesh. It is suitable for rice-maize cropping system and has been expanded rapidly in the northern districts of Bangladesh [4], mainly in response to increasing demand for poultry food [5]. Currently maize is planted to about 307,000 ha producing 2.12 million tons of grains annually [6]. In the Chittagong Hill Tracts (CHT) maize is grown since long as a secondary staple crop for the ethnic communities contributing to $2.1 \%$ of national production. With the advancement in breeding and biotechnology high yielding modern varieties and hybrids of maize are developed. In addition, improvement in agronomic management practices also contributes greatly to increasing grain yields [7]. However, the yield performance differs remarkably across hybrids depending on environmental conditions, agronomic management and choice of varieties. The growth and yield attributes of maize differ among and between local and hybrid maize varieties [8] [9]. Different agronomic management has different degrees of impact on growth and yield of maize. Among those agronomic management practices weeding is the most important one. Weed management practices significantly influenced the growth attributes at different growth stages [10]. White maize is most sensitive to weed competition during its early growth period. The growth of white maize plants in the first week is rather slow and weeds establish rapidly and become competitive during this period. Maximum weed competition in white maize occurs during 3 -and 14 leaf stage of plant development which is 2 to 6 weeks after sowing. It is important to maintain the fields weed free during this critical period of weed competition. Worldwide maize production is decreased to about $40 \%$ due to competition from weeds, which are the most dominant pest groups [11]. Another report shows that yield losses in maize fields due to weeds infestation range from 50\% - 90\% in Central and West Africa [12]. Weed control in white maize has not received adequate attention on the part of farmers and season in which weeding operations are performed depends on the availability of time, labor and cash. An appropriate weeding frequency can help to alleviate yield losses due to weeds. There are different kinds of weed control methods viz., Chemical methods, biological methods, hand weeding method etc. Different levels of hand weeding were used to conduct this experiment. Therefore, the objective of this 
work was set: to compare the growth and yield of different white maize varieties, to evaluate the performance of different weed control treatments on the performance of white maize varieties, to evaluate the interactions of white maize varieties and weed control treatments.

\section{Materials and Methods}

The present experiment was conducted at Agronomy farm of Sher-e-Bangla Agricultural University, Dhaka, Bangladesh. The location of the experimental site is $23^{\circ} 74^{\prime} \mathrm{N}$ latitude and $90^{\circ} 35^{\prime} \mathrm{E}$ longitude and at an elevation of $8.2 \mathrm{~m}$ from sea level. The experimental area was under the sub-tropical climate. The soil of the experimental area is medium high land having red brown terrace soil. Two factors were used in the present experiment to get 8 treatment combinations which were as Factor A: Variety (02) $\left(V_{1}=\right.$ Yangnuo-3000, $V_{2}=$ PSC-121). Factor B: Weed control treatments $(04)\left(\mathrm{T}_{0}=\right.$ No Weeding, $\mathrm{T}_{1}=$ One hand weeding at 60 DAS (days after sowing), $\mathrm{T}_{2}=$ Two hand weeding at 40 DAS (days after sowing) and 60 DAS (days after sowing), $\mathrm{T}_{3}=$ Weed free after 40 DAS (days after sowing)). Eight treatment combinations are as follows $-\mathrm{V}_{1} \mathrm{~T}_{0}, \mathrm{~V}_{1} \mathrm{~T}_{1}, \mathrm{~V}_{1} \mathrm{~T}_{2}$, $\mathrm{V}_{1} \mathrm{~T}_{3}, \mathrm{~V}_{2} \mathrm{~T}_{0}, \mathrm{~V}_{2} \mathrm{~T}_{1}, \mathrm{~V}_{2} \mathrm{~T}_{2}$ and $\mathrm{V}_{2} \mathrm{~T}_{3}$. The experiment was laid out in factorial RCBD with three replications. The total number of unit plots was 24 . The size of each unit plot was $2.40 \mathrm{~m} \times 2.50 \mathrm{~m}$. The distance maintained between the unit plots and blocks were $0.70 \mathrm{~m}$ and $1.0 \mathrm{~m}$ respectively. Healthy seeds of PSC-121 and Yangnuo-3000 were collected from the seed store of Krishi Gobesona Foundation. The experimental field was first opened on September, 2017 with the help of a power tiller and prepared by three successive plowing and cross-plowing followed by laddering. All kinds of weeds and residues of previous crop were removed from the field. Individual plots were cleaned and finally leveled with the help of wooden plank. Manures and fertilizers that were applied to the experimental plot presented in Table 1 . Total amount of TSP, MoP (murate of potassium), Gypsum, Zinc sulphate, Boric acid and half of Urea were applied as basal dose at the time of land preparation. The rest amount of Urea was applied at 25 days after seed sowing and before flowering. Seeds were sown on the $23^{\text {rd }}$ November, 2017 in line sowing method. Seeds were sown by maintaining the spacing of $60 \mathrm{~cm} \times 20 \mathrm{~cm}$ with two seeds per hill. The intercultural operations like thinning, irrigation were done for ensuring the normal growth of the experimental crop. Weeding was done as a part of the treatment factor B. The sampling was done consecutively at 40,60, 80 DAS and finally at harvest. At each sampling, five plants were selected randomly from each plot. The crop was harvested at $10^{\text {th }}$ April, 2018 when the leaves, stems become yellowish and the base of the grain turns into black color. After collecting the necessary data like Weed species present in the field, Weed density $\left(\right.$ no. $\left.\mathrm{m}^{-2}\right)$, Weed biomass $\left(\mathrm{g} \cdot \mathrm{m}^{-2}\right)$, Weed control efficiency (WCE \%), Plant height $(\mathrm{cm})$, Number of leaves pant ${ }^{-1}$, Number of grains $\mathrm{cob}^{-1}, 100$ grains weight (g), stover and grains (at final harvest) were oven dried at $60^{\circ} \mathrm{C}$ for 72 hours to record constant dry weights to 
Table 1. Dose and method of application of fertilizers in white maize field.

\begin{tabular}{ccc}
\hline Name of manure and fertilizer & Doses & Methods of application \\
\hline Cow dung & $5 \mathrm{t} \mathrm{ha}^{-1}$ & Total as basal \\
Urea & $525 \mathrm{~kg} \mathrm{ha}^{-1}$ & $1 / 3 \mathrm{rd}$ as basal and $2 / 3 \mathrm{rd}$ as top dressing \\
TSP & $250 \mathrm{~kg} \mathrm{ha}^{-1}$ & Total as basal \\
MoP & $200 \mathrm{~kg} \mathrm{ha}^{-1}$ & Total as basal \\
Gypsum & $250 \mathrm{~kg} \mathrm{ha}^{-1}$ & Total as basal \\
ZnSO $_{4}$ & $12.5 \mathrm{~kg} \mathrm{ha}^{-1}$ & Total as basal \\
Boric acid & $6.0 \mathrm{~kg} \mathrm{ha}^{-1}$ & Total as basal
\end{tabular}

Source: KGF, 2016.

collect the data like Grain yield $\left(\mathrm{t} \mathrm{ha}^{-1}\right)$, Stover yield $\left(\mathrm{t} \mathrm{ha}^{-1}\right)$ and Harvest index (\%).Weed control efficiency was analyzed by following the formula, WCE\% $=$ $\left\{\left(\mathrm{W}_{0}-\mathrm{W}_{\mathrm{t}}\right) / \mathrm{W}_{0} \times 100\right\}$ (Where, $\mathrm{WCE}=$ Weed control efficiency, $\mathrm{W}_{0}=$ No. weed present in per square meter of weedy check plot, $\mathrm{W}_{\mathrm{t}}=$ No. of weed present in per square meter of treated plot). The yield per hectare was computed by converting the yield per plant to yield per hectare by using the following relation: Yield per hectare $=[\{($ mean grain yield per plant $\times 83,000) \div 1000\} \div 1000] ;(83,000$ plants stand when planting spacing is maintained to $60 \mathrm{~cm} \times 20 \mathrm{~cm}$ ) [13]. After that the stover yield of the mean dry weight value of the five plants was derived by using the following formula: Stover Yield $=[\{$ (mean dry weight of shoot excluding cob $\times 83,000) \div 1000\} \div 1000]$; $(83,000$ plants stand when planting spacing is maintained to $60 \mathrm{~cm} \times 20 \mathrm{~cm}$ ) [13]. The following formula was used to calculate. Harvest index $(\%)=\{($ Grain yield/Biological yield $) \times 100\}$. The analyses of variance were done following RCBD (factorial) with the help of a computer package program Statistix-10. The mean values were compared using LSD at 5\% level of significance.

\section{Results and Discussion}

The results obtained from the study have been presented, discussed and the possible interpretation has also been given under the following headings.

\subsection{Weed Parameters}

Figure 1 shows the effect of variety on weed parameters. From the experiment it was found that though there was a numerical difference between the varieties in terms of weed parameters but the difference was not statistically similar. Higher weed population $\left(118.33\right.$ no. $\left.\mathrm{m}^{-2}\right)$ and weed biomass $\left(74.42 \mathrm{~g} \cdot \mathrm{m}^{-2}\right)$ was found from $V_{1}$ as compared to that of $V_{2}$. On the other hand, the maximum weed control efficiency (46.32\%) was recorded from $\mathrm{V}_{2}$ as compared to that of $\mathrm{V}_{1}(44.92 \%)$. PSC-121 was reported as better performer than Yangnuo-3000 in terms of most of the growth parameters [14]. 


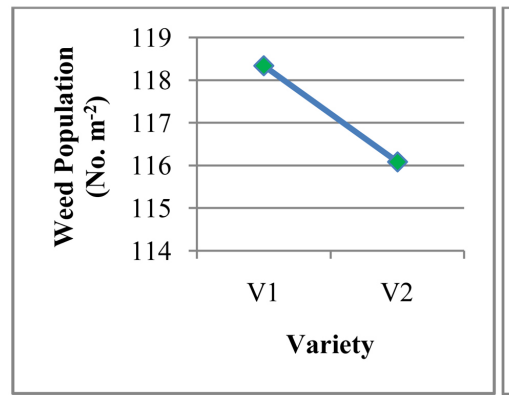

(a)

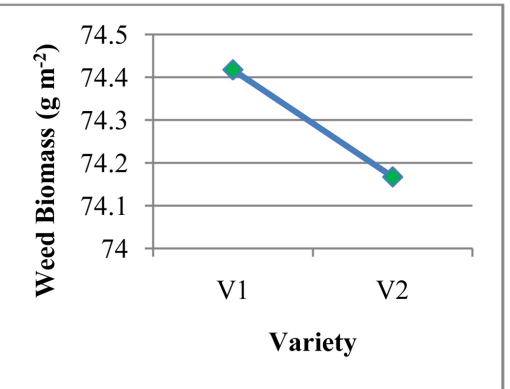

(b)

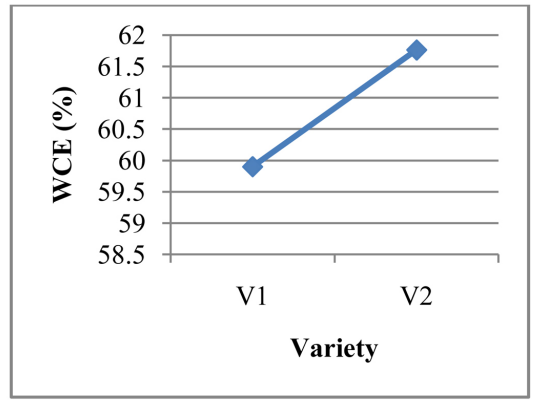

(c)

Figure 1. Effect of variety on weed parameters [(a): Weed Population (no. $\mathrm{m}^{-2}$ ); (b): Weed Biomass $\left(\mathrm{g} \cdot \mathrm{m}^{-2}\right)$; (c): Weed Control Efficiency (WCE\%)]. $\mathrm{V}_{1}=$ YANGNUO-3000, $\mathrm{V}_{2}=$ PSC-121 $\left(\mathrm{LSD}_{0.05}=9.60,5.80\right.$ and 3.52 for (a), (b) and (c) respectively).

The weed community of the experimental field was comprised of Eleusine indica, Cyperus rotundus, Cynodon dactylon, Jussiaea repens, Commelina benghalensis, Physalis heterophylla, Desmodium trifolia, Brassica kaber. Among the weed species, Eleusine indica was of most abundant one counting more than fifty percent of total weed community were present in per square meter of the experimental field. From the experiment it was revealed that the $\mathrm{T}_{3}$ (Weed free after 40 DAS) treated plots showed supreme result regarding reduced weed density $\left(12.17\right.$ no. $\left.\mathrm{m}^{-2}\right)$, minimum weed biomass $\left(4.33 \mathrm{~g} \cdot \mathrm{m}^{-2}\right)$ and weed control efficiency $(94.38 \%)$ and it was followed by $\mathrm{T}_{2}$ (two hand weeding at 40 DAS and 60 DAS) (Table 2). However, $T_{0}$ gave the worst result giving the highest weed density in terms of both weed number and biomass per meter square. All the four treatments were significantly different from each other in terms of weed density (no. $\mathrm{m}^{-2}$ ), weed biomass $\left(\mathrm{g} \cdot \mathrm{m}^{-2}\right.$ ) and weed control efficiency. Atrazine $1 \mathrm{~kg} \mathrm{ha}^{-1}$ with hand weeding and 2 hand weeding with paddy straw mulching that helps to minimize weed population [15].

Interaction effect of variety and weed control treatments are presented in the Table 3. There was no significant difference among the treatments. From the experiment it was observed that $\mathrm{V}_{2} \mathrm{~T}_{0}$ showed the maximum weed density $\left(211.67\right.$ no. $\left.\mathrm{m}^{-2}\right)$ and it was statistically similar with that of $\mathrm{V}_{1} \mathrm{~T}_{0}$. However, the lowest weed density (11.67 no. $\mathrm{m}^{-2}$ ) was recorded from $\mathrm{V}_{1} \mathrm{~T}_{3}$. In case of weed biomass, the highest result $\left(153.33 \mathrm{~g} \cdot \mathrm{m}^{-2}\right)$ was recorded from $\mathrm{V}_{1} \mathrm{~T}_{0}$ whereas the lowest one was recorded from $\mathrm{V}_{1} \mathrm{~T}_{3}$ and $\mathrm{V}_{2} \mathrm{~T}_{3}$ simultaneously. On other hand, the 
Table 2. Effect of weed control treatments on weed density, biomass and weed control efficiency at harvest.

\begin{tabular}{cccc}
\hline Treatments & $\begin{array}{c}\text { Weed density } \\
\left(\text { No. } \mathbf{~ m}^{-2}\right)\end{array}$ & $\begin{array}{c}\text { Weed biomass } \\
\left(\mathrm{g} \cdot \mathrm{m}^{-2}\right)\end{array}$ & WCE (\%) \\
\hline $\mathrm{T}_{0}$ & $216.00 \mathrm{a}$ & $153.17 \mathrm{a}$ & $0.00 \mathrm{~d}$ \\
$\mathrm{~T}_{1}$ & $154.83 \mathrm{~b}$ & $96.33 \mathrm{~b}$ & $27.94 \mathrm{c}$ \\
$\mathrm{T}_{2}$ & $85.83 \mathrm{c}$ & $43.33 \mathrm{c}$ & $60.16 \mathrm{~b}$ \\
$\mathrm{~T}_{3}$ & $12.17 \mathrm{~d}$ & $4.33 \mathrm{~d}$ & $94.38 \mathrm{a}$ \\
$\mathrm{LSD}_{(0.05)}$ & 13.58 & $\mathbf{8 . 2 1}$ & 4.99 \\
$\mathrm{CV}(\%)$ & 9.36 & $\mathbf{8 . 9 3}$ & $\mathbf{8 . 8 3}$ \\
\hline
\end{tabular}

$\mathrm{T}_{0}=$ no weeding; $\mathrm{T}_{1}=$ one hand weeding at $60 \mathrm{DAS} ; \mathrm{T}_{2}=$ two hand weeding at $40 \mathrm{DAS}$ and $60 \mathrm{DAS} ; \mathrm{T}_{3}=$ weed free after 40 DAS.

Table 3. Interaction effect of variety and weed control treatments on weed parameters.

\begin{tabular}{cccc}
\hline Treatments & $\begin{array}{c}\text { Weed density } \\
\left(\text { No. } \mathbf{m}^{-2}\right)\end{array}$ & $\begin{array}{c}\text { Weed biomass } \\
\left(\mathrm{g} \cdot \mathrm{m}^{-2}\right)\end{array}$ & WCE (\%) \\
\hline $\mathrm{V}_{1} \mathrm{~T}_{0}$ & $220.33 \mathrm{a}$ & $153.33 \mathrm{a}$ & $0.00 \mathrm{~d}$ \\
$\mathrm{~V}_{1} \mathrm{~T}_{1}$ & $157.67 \mathrm{~b}$ & $99.33 \mathrm{~b}$ & $27.51 \mathrm{c}$ \\
$\mathrm{V}_{1} \mathrm{~T}_{2}$ & $83.67 \mathrm{c}$ & $40.67 \mathrm{c}$ & $58.13 \mathrm{~b}$ \\
$\mathrm{~V}_{1} \mathrm{~T}_{3}$ & $11.67 \mathrm{~d}$ & $4.33 \mathrm{~d}$ & $94.04 \mathrm{a}$ \\
$\mathrm{V}_{2} \mathrm{~T}_{0}$ & $211.67 \mathrm{a}$ & $153.00 \mathrm{a}$ & $0.00 \mathrm{~d}$ \\
$\mathrm{~V}_{2} \mathrm{~T}_{1}$ & $152.00 \mathrm{~b}$ & $93.33 \mathrm{~b}$ & $28.36 \mathrm{c}$ \\
$\mathrm{V}_{2} \mathrm{~T}_{2}$ & $88.00 \mathrm{c}$ & $46.00 \mathrm{c}$ & $62.19 \mathrm{~b}$ \\
$\mathrm{~V}_{2} \mathrm{~T}_{3}$ & $12.67 \mathrm{~d}$ & $4.33 \mathrm{~d}$ & $94.72 \mathrm{a}$ \\
$\mathrm{LSD}_{(0.05)}$ & 19.20 & 11.61 & 7.05 \\
$\mathrm{CV}_{(\%)}$ & 9.36 & 8.93 & 8.83 \\
\hline
\end{tabular}

$\mathrm{V}_{1}=$ YANGNUO-3000; $\mathrm{V}_{2}=$ PSC-121; $\mathrm{T}_{0}=$ no weeding; $\mathrm{T}_{1}=$ one hand weeding at $60 \mathrm{DAS} ; \mathrm{T}_{2}=$ two hand weeding at $40 \mathrm{DAS}$ and $60 \mathrm{DAS} ; \mathrm{T}_{3}=$ weed free after $40 \mathrm{DAS}$.

highest weed control efficiency $(94.72 \%)$ was recorded from $\mathrm{V}_{2} \mathrm{~T}_{3}$ which was statistically similar with that of $\mathrm{V}_{1} \mathrm{~T}_{3}$.

\subsection{Growth Parameters}

\subsubsection{Plant Height (cm)}

Table 4 shows the variety have a significant effect on plant height at all stages except 80 DAS and harvest stage. In all four stages $(40,60,80$ DAS and at harvest) $\mathrm{V}_{2}$ showed the highest plant height $(85.63 \mathrm{~cm}, 121.38 \mathrm{~cm}, 172.75 \mathrm{~cm}$ and $203.68 \mathrm{~cm}$ at $40,60,80 \mathrm{DAS}$ and at harvest respectively) over $\mathrm{V}_{1}$. The white maize modern variety (Suvra) showed the highest value of plant height over landraces (plough 201 and plough 202) while conducting an experiment in Bangladesh [9].

Influence of weed control treatments on plant height is shown on Table 5 . The highest plant heights $(83.00 \mathrm{~cm}, 121.25 \mathrm{~cm}, 180.33 \mathrm{~cm}$ and $204.03 \mathrm{~cm}$ at 40 , 60,80 DAS and at harvest respectively) were recorded from $\mathrm{T}_{3}$ followed by $\mathrm{T}_{2}$. 
Table 4. Effect of variety on growth parameter.

\begin{tabular}{ccccccccc}
\hline \multirow{2}{*}{ Variety } & \multicolumn{3}{c}{ Plant height $(\mathrm{cm})$} & \multicolumn{5}{c}{ Number of leaves per plant } \\
\cline { 2 - 8 } & 40 DAS & 60 DAS & $\mathbf{8 0}$ DAS & Harvest & 40 DAS & 60 DAS & 90 DAS & Harvest \\
\hline $\mathrm{V}_{1}$ & $70.45 \mathrm{~b}$ & $107.12 \mathrm{~b}$ & $172.35 \mathrm{a}$ & $188.58 \mathrm{a}$ & $4.61 \mathrm{a}$ & $8.75 \mathrm{~b}$ & $11.833 \mathrm{a}$ & $12.4 \mathrm{~b}$ \\
$\mathrm{~V}_{2}$ & $85.63 \mathrm{a}$ & $121.38 \mathrm{a}$ & $172.75 \mathrm{a}$ & $203.68 \mathrm{a}$ & $4.75 \mathrm{a}$ & $11.04 \mathrm{a}$ & $12.5 \mathrm{a}$ & $13.29 \mathrm{a}$ \\
$\mathrm{LSD}_{(0.05)}$ & $\mathbf{3 . 6 0}$ & $\mathbf{7 . 9 2}$ & $\mathrm{ns}$ & $\mathrm{ns}$ & $\mathrm{ns}$ & $\mathbf{0 . 8 8}$ & $\mathrm{ns}$ & $\mathbf{0 . 6 4}$ \\
\hline
\end{tabular}

$\mathrm{V}_{1}=$ YANGNUO-3000 and $\mathrm{V}_{2}=$ PSC-121, ns = nonsignificant.

Table 5. Effect of weed control treatments on growth parameter.

\begin{tabular}{ccccccccc}
\hline \multirow{2}{*}{$\begin{array}{c}\text { Weed control } \\
\text { treatments }\end{array}$} & \multicolumn{4}{c}{ Plant height $(\mathrm{cm})$} & \multicolumn{4}{c}{ Number of leaves per plant } \\
\cline { 2 - 8 } & 40 DAS & 60 DAS & 80 DAS & Harvest & 40 DAS & 60 DAS & 90 DAS & Harvest \\
\hline $\mathrm{T}_{0}$ & $72.68 \mathrm{c}$ & $106.85 \mathrm{~b}$ & $156.92 \mathrm{~b}$ & $188.89 \mathrm{~b}$ & $4.61 \mathrm{a}$ & $9.42 \mathrm{~b}$ & $12 \mathrm{a}$ & $12.73 \mathrm{a}$ \\
$\mathrm{T}_{1}$ & $76.27 \mathrm{bc}$ & $112.67 \mathrm{ab}$ & $176.12 \mathrm{a}$ & $194.03 \mathrm{ab}$ & $4.61 \mathrm{a}$ & $9.5 \mathrm{~b}$ & $12 \mathrm{a}$ & $12.77 \mathrm{a}$ \\
$\mathrm{T}_{2}$ & $80.20 \mathrm{ab}$ & $116.25 \mathrm{ab}$ & $176.83 \mathrm{a}$ & $197.57 \mathrm{ab}$ & $4.72 \mathrm{a}$ & $9.92 \mathrm{ab}$ & $12.33 \mathrm{a}$ & $12.85 \mathrm{a}$ \\
$\mathrm{T}_{3}$ & $83.00 \mathrm{a}$ & $121.25 \mathrm{a}$ & $180.33 \mathrm{a}$ & $204.03 \mathrm{a}$ & $4.78 \mathrm{a}$ & $10.75 \mathrm{a}$ & $12.33 \mathrm{a}$ & $13.03 \mathrm{a}$ \\
LSD $_{(0.05)}$ & 5.09 & 11.20 & 13.12 & 13.86 & $\mathrm{~ns}$ & 1.24 & $\mathrm{~ns}$ & $\mathrm{~ns}$ \\
\hline
\end{tabular}

$\mathrm{T}_{0}=$ no weeding; $\mathrm{T}_{1}=$ one hand weeding at $60 \mathrm{DAS} ; \mathrm{T}_{2}=$ two hand weeding at $40 \mathrm{DAS}$ and $60 \mathrm{DAS} ; \mathrm{T}_{3}=$ weed free after $40 \mathrm{DAS}$ and $\mathrm{ns}=$ nonsignificant.

Both $\mathrm{T}_{3}$ and $\mathrm{T}_{2}$ were statistically similar to each other. The lowest plant heights were recorded from $\mathrm{T}_{0}$ and it was statistically similar with $\mathrm{T}_{1}$ at all four stages except 80 DAS. Weed management practices have no significantly influence on growth attributes as plant height at different growth stages.

Interaction effect of variety and weed control treatments are listed in Table 6. No significant difference among the means was recorded. In case of plant height at 40 DAS and at harvest, the highest $(90.89 \mathrm{~cm}$ and $217.00 \mathrm{~cm}$ respectively) and the lowest $(63.23 \mathrm{~cm}$ and $176.58 \mathrm{~cm}$ respectively) plant height was found from $\mathrm{V}_{2} \mathrm{~T}_{3}$ and $\mathrm{V}_{1} \mathrm{~T}_{0}$. While, the maximum and the minimum plant height of 128.5 $\left(\mathrm{V}_{2} \mathrm{~T}_{1}\right) \mathrm{cm}$ and $96.83 \mathrm{~cm}\left(\mathrm{~V}_{1} \mathrm{~T}_{1}\right)$ respectively were recorded at $60 \mathrm{DAS}$. In case of $80 \mathrm{DAS}, \mathrm{V}_{2} \mathrm{~T}_{3}$ showed the highest plant height $(184.00 \mathrm{~cm})$ and $\mathrm{V}_{2} \mathrm{~T}_{0}$ showed the lowest plant height of $150.00 \mathrm{~cm}$.

\subsubsection{Leaf Number Plant ${ }^{-1}$}

Table 4 represents the significant difference between varieties regarding leaf number plant ${ }^{-1}$ at $60 \mathrm{DAS}$ and at harvest. At 40 and 80 DAS the parameter was not significant between varieties. The maximum leaf number plant ${ }^{-1}(4.75,11.04$, 12.5 and 13.29 at 40,60,80 DAS and at harvest respectively) was recorded from $\mathrm{V}_{2}$ and the lowest result was obtained from $\mathrm{V}_{1}$. The number of leaves in the modern varieties differed from 11.66 to 13.66 plant $^{-1}$ with a mean value of 12.88 plant $^{-1}[9]$.

Influence of different weed control treatments are shown in Table 5. There was no significant difference among the weed control treatments regarding leaf number plant ${ }^{-1}$. The highest leaf number plant ${ }^{-1}$ was recorded from $T_{3}$ followed by $\mathrm{T}_{2}$. The lowest outcome was recorded from $\mathrm{T}_{0}$. Initial stage of growth 
Table 6. Interaction effect of variety and weed control treatments on growth parameter.

\begin{tabular}{|c|c|c|c|c|c|c|c|c|}
\hline \multirow{2}{*}{$\begin{array}{c}\text { Treatment } \\
\text { Combinations }\end{array}$} & \multicolumn{4}{|c|}{ Plant height $(\mathrm{cm})$} & \multicolumn{4}{|c|}{ Number of leaves per plant } \\
\hline & 40 DAS & 60 DAS & $\begin{array}{c}80 \\
\text { DAS }\end{array}$ & Harvest & 40 DAS & 60 DAS & 80 DAS & harvest \\
\hline $\mathrm{V}_{1} \mathrm{~T}_{0}$ & $63.23 \mathrm{e}$ & $110.83 \mathrm{~b}-\mathrm{d}$ & $163.83 \mathrm{bc}$ & $176.58 \mathrm{c}$ & $4.44 \mathrm{a}$ & $7.66 \mathrm{e}$ & $12.00 \mathrm{a}$ & $12.40 \mathrm{ab}$ \\
\hline $\mathrm{V}_{1} \mathrm{~T}_{1}$ & $68.66 \mathrm{de}$ & $96.83 \mathrm{~d}$ & $176.57 \mathrm{ab}$ & $194.00 \mathrm{bc}$ & $4.56 \mathrm{a}$ & $9.00 \mathrm{de}$ & $11.33 \mathrm{a}$ & $11.86 \mathrm{~b}$ \\
\hline $\mathrm{V}_{1} \mathrm{~T}_{2}$ & $74.77 \mathrm{~d}$ & $104.83 \mathrm{~cd}$ & $172.33 \mathrm{ab}$ & $192.67 \mathrm{bc}$ & $4.89 \mathrm{a}$ & $9.00 \mathrm{de}$ & $12.00 \mathrm{a}$ & $12.46 \mathrm{ab}$ \\
\hline $\mathrm{V}_{1} \mathrm{~T}_{3}$ & $75.11 \mathrm{~cd}$ & $116.00 \mathrm{a}-\mathrm{c}$ & $176.67 \mathrm{ab}$ & $191.07 \mathrm{bc}$ & $4.56 \mathrm{a}$ & $9.33 c-e$ & $12.00 \mathrm{a}$ & $12.86 \mathrm{ab}$ \\
\hline $\mathrm{V}_{2} \mathrm{~T}_{0}$ & $82.11 b c$ & $102.87 \mathrm{~cd}$ & $150.00 \mathrm{c}$ & $201.20 \mathrm{ab}$ & $4.78 \mathrm{a}$ & $11.16 \mathrm{ab}$ & $12.00 \mathrm{a}$ & $13.06 \mathrm{ab}$ \\
\hline $\mathrm{V}_{2} \mathrm{~T}_{1}$ & $83.87 \mathrm{ab}$ & $128.50 \mathrm{a}$ & $175.67 \mathrm{ab}$ & $194.07 \mathrm{bc}$ & $4.67 \mathrm{a}$ & $10.00 \mathrm{~b}-\mathrm{d}$ & $12.67 \mathrm{a}$ & $13.66 \mathrm{a}$ \\
\hline $\mathrm{V}_{2} \mathrm{~T}_{2}$ & $85.63 \mathrm{ab}$ & 127.67 a & $181.33 \mathrm{ab}$ & $202.47 \mathrm{ab}$ & $4.56 \mathrm{a}$ & $10.83 \mathrm{a}-\mathrm{c}$ & $12.67 \mathrm{a}$ & $13.23 \mathrm{a}$ \\
\hline $\mathrm{V}_{2} \mathrm{~T}_{3}$ & $90.89 \mathrm{a}$ & $126.50 \mathrm{ab}$ & $184.00 \mathrm{a}$ & $217.00 \mathrm{a}$ & $5.00 \mathrm{a}$ & $12.16 \mathrm{a}$ & $12.67 \mathrm{a}$ & $13.20 \mathrm{a}$ \\
\hline $\operatorname{LSD}_{(0.05)}$ & 7.20 & 15.84 & 18.55 & 19.60 & ns & 1.76 & ns & 1.28 \\
\hline $\mathrm{CV}(\%)$ & 5.27 & 7.92 & 6.14 & 5.71 & 9.50 & 10.20 & 7.48 & 5.70 \\
\hline
\end{tabular}

$\mathrm{V}_{1}=$ YANGNUO-3000; $\mathrm{V}_{2}=$ PSC-121; $\mathrm{T}_{0}=$ no weeding; $\mathrm{T}_{1}=$ one hand weeding at $60 \mathrm{DAS} ; \mathrm{T}_{2}=$ two hand weeding at $40 \mathrm{DAS}$ and $60 \mathrm{DAS} ; \mathrm{T}_{3}=$ weed free after $40 \mathrm{DAS}$ and $\mathrm{ns}=$ nonsignificant.

maize is highly susceptible to weed competition [16].

Table 6 shows that there was no significant difference among the interactions in all four stages. The maximum number of leaf plant ${ }^{-1}(5.00,12.17$ and 12.67$)$ at 40, 60 and 80 DAS respectively from $\mathrm{V}_{2} \mathrm{~T}_{3}$ while, at harvest, the maximum number of leaf plant ${ }^{-1}$ was recorded from $\mathrm{V}_{2} \mathrm{~T}_{1}$ (13.67). The minimum number of leaf plant $^{-1}$ was recorded from $\mathrm{V}_{1} \mathrm{~T}_{0}$ (4.44 and 7.67 at 40 and 60 DAS respectively) and $\mathrm{V}_{1} \mathrm{~T}_{1}$ (11.33 and 11.87 at $80 \mathrm{DAS}$ and at harvest respectively).

\subsection{Yield Parameters}

\subsubsection{Number of Grains Cob $^{-1}$}

Effect of variety on number of grains $\mathrm{cob}^{-1}$ is shown in Table 7. From the experiment it was found that there was significant difference between varieties regarding the number of grains $\operatorname{cob}^{-1} . \mathrm{V}_{2}$ showed the maximum number of grains $\operatorname{cob}^{-1}$ (468.75) over $\mathrm{V}_{1}$ (427.06).

Table 8 revealed that the effect of weed control treatments on number of grains $\mathrm{cob}^{-1}$. The highest number of grains $\mathrm{cob}^{-1}$ was recorded from $\mathrm{T}_{3}(464.54)$ which followed by $\mathrm{T}_{2}$. The lowest number of grains $\mathrm{cob}^{-1}$ was obtained from $\mathrm{T}_{0}$ (418.53). $\mathrm{T}_{3}$ and $\mathrm{T}_{2}$ were statistically significant over $\mathrm{T}_{0}$. The highest number of grains $\mathrm{cob}^{-1}$ come from hand weeded plot over the no weeding and other treatment plots [5] [17].

The experiment revealed that there was no significant statistical difference among weed control treatments irrespective of numerical difference among treatments (Table 9). From the experiment it was revealed that the maximum number of grains $\operatorname{cob}^{-1}$ (494.97) was given by $\mathrm{V}_{2} \mathrm{~T}_{3}$. However, $\mathrm{V}_{2} \mathrm{~T}_{1}$ and $\mathrm{V}_{1} \mathrm{~T}_{2}$ were statistically similar with $\mathrm{V}_{2} \mathrm{~T}_{3}$. The minimum number of grains $\operatorname{cob}^{-1}$ (375.72) was recorded from $V_{1} T_{0}$. 
Table 7. Effect of variety on yield parameter.

\begin{tabular}{cccccc}
\hline Variety & $\begin{array}{c}\text { Number of } \\
\text { grains cob }\end{array}$ & $\begin{array}{c}\text { 100 grains } \\
\text { weight }(\mathrm{g})\end{array}$ & $\begin{array}{c}\text { Grain yield } \\
(\mathrm{t} / \mathrm{ha})\end{array}$ & $\begin{array}{c}\text { Stover yield } \\
(\mathrm{t} / \mathrm{ha})\end{array}$ & $\begin{array}{c}\text { Harvest } \\
\text { Index (\%) }\end{array}$ \\
\hline $\mathrm{V}_{1}$ & $427.06 \mathrm{~b}$ & $32.25 \mathrm{~b}$ & $7.37 \mathrm{~b}$ & $6.45 \mathrm{a}$ & $53.06 \mathrm{a}$ \\
$\mathrm{V}_{2}$ & $468.75 \mathrm{a}$ & $35.08 \mathrm{a}$ & $8.28 \mathrm{a}$ & $6.56 \mathrm{a}$ & $55.85 \mathrm{a}$ \\
$\mathrm{LSD}_{(0.05)}$ & $\mathbf{0 . 6 9}$ & 1.39 & $\mathbf{0 . 5 8}$ & $\mathrm{ns}$ & $\mathrm{ns}$ \\
\hline
\end{tabular}

$\mathrm{V}_{1}=$ YANGNUO-3000 and $\mathrm{V}_{2}=$ PSC-121 and ns = nonsignificant.

Table 8. Effect of weed control treatments on yield parameter.

\begin{tabular}{cccccc}
\hline $\begin{array}{c}\text { Weed control } \\
\text { treatments }\end{array}$ & $\begin{array}{c}\text { Number of } \\
\text { grains cob }\end{array}$ & $\begin{array}{c}100 \text { grains } \\
\text { weight }(\mathrm{g})\end{array}$ & $\begin{array}{c}\text { Grain yield } \\
(\mathrm{t} / \mathrm{ha})\end{array}$ & $\begin{array}{c}\text { Stover } \\
\text { yield (t/ha) }\end{array}$ & $\begin{array}{c}\text { Harvest } \\
\text { Index (\%) }\end{array}$ \\
\hline $\mathrm{T}_{0}$ & $418.53 \mathrm{~b}$ & $29.67 \mathrm{~d}$ & $6.77 \mathrm{c}$ & $5.33 \mathrm{c}$ & $55.46 \mathrm{a}$ \\
$\mathrm{T}_{1}$ & $447.15 \mathrm{a}$ & $33 \mathrm{c}$ & $7.21 \mathrm{c}$ & $6.47 \mathrm{~b}$ & $52.64 \mathrm{a}$ \\
$\mathrm{T}_{2}$ & $461.41 \mathrm{a}$ & $35 \mathrm{~b}$ & $8.08 \mathrm{~b}$ & $6.76 \mathrm{ab}$ & $54.36 \mathrm{a}$ \\
$\mathrm{T}_{3}$ & $464.54 \mathrm{a}$ & $37 \mathrm{a}$ & $9.25 \mathrm{a}$ & $7.46 \mathrm{a}$ & $55.36 \mathrm{a}$ \\
$\mathrm{LSD}_{(0.05)}$ & 0.97 & 1.97 & $\mathbf{0 . 8 2}$ & $\mathbf{0 . 7 8}$ & $\mathrm{ns}$ \\
\hline
\end{tabular}

$\mathrm{T}_{0}=$ no weeding; $\mathrm{T}_{1}=$ one hand weeding at $60 \mathrm{DAS} ; \mathrm{T}_{2}=$ two hand weeding at $40 \mathrm{DAS}$ and $60 \mathrm{DAS} ; \mathrm{T}_{3}=$ weed free after 40 DAS and ns = nonsignificant.

Table 9. Interaction effect of variety and weed control treatments on yield parameter.

\begin{tabular}{cccccc}
\hline $\begin{array}{c}\text { Treatment } \\
\text { Combinations }\end{array}$ & $\begin{array}{c}\text { Number of } \\
\text { grains cob }\end{array}$ & $\begin{array}{c}100 \text { grains } \\
\text { weight }(\mathrm{g})\end{array}$ & $\begin{array}{c}\text { Grain yield } \\
(\mathrm{t} / \mathrm{ha})\end{array}$ & $\begin{array}{c}\text { Stover yield } \\
(\mathrm{t} / \mathrm{ha})\end{array}$ & $\begin{array}{c}\text { Harvest } \\
\text { Index (\%) }\end{array}$ \\
\hline $\mathrm{V}_{1} \mathrm{~T}_{0}$ & $375.72 \mathrm{c}$ & $28.66 \mathrm{e}$ & $5.49 \mathrm{~d}$ & $5.08 \mathrm{~d}$ & $51.92 \mathrm{~b}$ \\
$\mathrm{~V}_{1} \mathrm{~T}_{1}$ & $432.48 \mathrm{~b}$ & $32.33 \mathrm{~cd}$ & $6.38 \mathrm{~d}$ & $6.14 \mathrm{bcd}$ & $50.94 \mathrm{~b}$ \\
$\mathrm{~V}_{1} \mathrm{~T}_{2}$ & $465.94 \mathrm{ab}$ & $32.00 \mathrm{~cd}$ & $8.44 \mathrm{abc}$ & $6.97 \mathrm{ab}$ & $54.76 \mathrm{ab}$ \\
$\mathrm{V}_{1} \mathrm{~T}_{3}$ & $434.11 \mathrm{~b}$ & $36.00 \mathrm{ab}$ & $9.17 \mathrm{ab}$ & $7.61 \mathrm{a}$ & $54.61 \mathrm{ab}$ \\
$\mathrm{V}_{2} \mathrm{~T}_{0}$ & $461.33 \mathrm{~b}$ & $30.66 \mathrm{de}$ & $8.03 \mathrm{bc}$ & $5.58 \mathrm{~cd}$ & $59.00 \mathrm{a}$ \\
$\mathrm{V}_{2} \mathrm{~T}_{1}$ & $461.82 \mathrm{ab}$ & $33.66 \mathrm{bc}$ & $8.05 \mathrm{bc}$ & $6.80 \mathrm{ab}$ & $54.33 \mathrm{ab}$ \\
$\mathrm{V}_{2} \mathrm{~T}_{2}$ & $456.87 \mathrm{~b}$ & $38.00 \mathrm{a}$ & $7.71 \mathrm{c}$ & $6.54 \mathrm{abc}$ & $53.96 \mathrm{ab}$ \\
$\mathrm{V}_{2} \mathrm{~T}_{3}$ & $494.97 \mathrm{a}$ & $38.00 \mathrm{a}$ & $9.33 \mathrm{a}$ & $7.30 \mathrm{a}$ & $56.09 \mathrm{ab}$ \\
$\mathrm{LSD}_{(0.05)}$ & 33.58 & 2.79 & 1.16 & 1.11 & 5.93 \\
$\mathrm{CV}_{(\%)}$ & 4.28 & 4.74 & 8.46 & 9.78 & 6.22 \\
\hline
\end{tabular}

$\mathrm{V}_{1}=$ YANGNUO-3000; $\mathrm{V}_{2}=$ PSC-121; $\mathrm{T}_{0}=$ no weeding; $\mathrm{T}_{1}=$ one hand weeding at $60 \mathrm{DAS} ; \mathrm{T}_{2}=$ two hand weeding at $40 \mathrm{DAS}$ and $60 \mathrm{DAS} ; \mathrm{T}_{3}=$ weed free after $40 \mathrm{DAS}$.

\subsubsection{Grains Weight (g)}

Table 7 shows the significant effect of variety on 100 grains weight. The maximum weight of 100 grains ( $35.08 \mathrm{~g}$ ) per cob was found from $\mathrm{V}_{2} . \mathrm{V}_{1}$ showed the 100 grains weight of about $32.25 \mathrm{~g}$. PSC-121 was reported as better performer than Yangnuo-3000 in terms of most of the yield parameters [14].

Table 8 represents the effect of weed control treatments on 100 grains weight. From the experiment it was found that the treatments were statistically significant. The highest 100 grains weight was recorded from $T_{3}(37.0 \mathrm{~g})$ which was followed by $\mathrm{T}_{2}(35.0 \mathrm{~g})$. The lowest weight of 100 grains per cob was obtained 
from $\mathrm{T}_{0}(29.67 \mathrm{~g})$.

Interaction effect of variety and weed control treatments on 100 grains weight is placed in Table 9. From the experiment it was obtained that the highest weight of 100 grains $\left(38.0 \mathrm{~g}\right.$ ) was obtained from $\mathrm{V}_{2} \mathrm{~T}_{3}$ and $\mathrm{V}_{2} \mathrm{~T}_{2}$ simultaneously and they were statistically similar with each other. The lowest weight of 100 grains $(28.67 \mathrm{~g})$ was recorded from $\mathrm{V}_{1} \mathrm{~T}_{0}$.

\subsubsection{Grain Yield ( $\mathrm{tha} \mathrm{a}^{-1}$ ) and Stover Yield ( $\left.\mathrm{t} \mathrm{ha} \mathrm{a}^{-1}\right)$}

Table 7 represents the effect of variety on grain and stover yield. In case of grain yield, a significant difference between varieties was found. However, the difference was not significant in case of stover yield. The maximum grain yield $(8.28 \mathrm{t}$ $\mathrm{ha}^{-1}$ ) and stover yield $\left(6.56 \mathrm{t} \mathrm{ha}^{-1}\right)$ were recorded from $\mathrm{V}_{2}$. On the other hand, the minimum grain yield $\left(7.37 \mathrm{t} \mathrm{ha}^{-1}\right)$ and stover yield $\left(6.45 \mathrm{t} \mathrm{ha}^{-1}\right)$ was obtained from $V_{1}$. PSC-121 was reported as better performer than Yangnuo-3000 in terms of most of the yield parameters and giving grain yield of $7.76 \mathrm{t} \mathrm{ha}^{-1}$ where grain yield of $6.44 \mathrm{tha}^{-1}$ was obtained from Yangnuo-3000 [1].

Effect of weed control measures on grain yield $\left(\mathrm{t} \mathrm{ha}^{-1}\right)$ and stover yield $\left(\mathrm{t} \mathrm{ha}^{-1}\right)$ is showed in Table 8. In case of grain yield, the best result $\left(9.25 \mathrm{t} \mathrm{ha}^{-1}\right)$ was obtained from $\mathrm{T}_{3}$ and it was followed by $\mathrm{T}_{2}\left(8.08 \mathrm{t} \mathrm{ha}^{-1}\right)$. There was a statistically significant difference between $\mathrm{T}_{3}$ and $\mathrm{T}_{2}$. On the other hand, the maximum stover yield was given by $\mathrm{T}_{3}\left(7.46 \mathrm{tha}^{-1}\right)$ which was followed by $\mathrm{T}_{2}\left(6.76 \mathrm{tha}^{-1}\right)$. However, the difference between $\mathrm{T}_{3}$ and $\mathrm{T}_{2}$ was not significant. In case of both grain yield and stover yield the minimum finding was recorded from $\mathrm{T}_{0}(6.77 \mathrm{t}$ $\mathrm{ha}^{-1}$ and $5.33 \mathrm{t} \mathrm{ha}^{-1}$ respectively). $\mathrm{T}_{0}$ varied from other weed control treatments significantly in respect of grain yield and stover yield.

Interaction effect of variety and weed control treatment interaction on grain yield $\left(\mathrm{t} \mathrm{ha}^{-1}\right)$ and stover yield $\left(\mathrm{t} \mathrm{ha}^{-1}\right)$ is shown in Table 9 . From the experiment it was found that the maximum grains yield $\left(9.33 \mathrm{t} \mathrm{ha}^{-1}\right)$ and stover yield $(7.61 \mathrm{t}$ $\mathrm{ha}^{-1}$ ) was obtained from $\mathrm{V}_{2} \mathrm{~T}_{3}$ and $\mathrm{V}_{1} \mathrm{~T}_{3}$ respectively. $\mathrm{V}_{1} \mathrm{~T}_{2}$ interactions showed the best result out of $\mathrm{V}_{1} \mathrm{~T}_{3}$ and $\mathrm{V}_{2} \mathrm{~T}_{3}$ interactions in case of both grain yield and stover yield. The minimum grain yield $\left(5.49 \mathrm{tha}^{-1}\right)$ and stover yield $\left(5.08 \mathrm{tha}^{-1}\right)$ was given by $\mathrm{V}_{1} \mathrm{~T}_{0}$. There were a statistically significant difference among $\mathrm{V}_{1} \mathrm{~T}_{0}$ with $\mathrm{V}_{1} \mathrm{~T}_{3}$ and $\mathrm{V}_{2} \mathrm{~T}_{3}$.

\subsubsection{Harvest Index (\%)}

Effect of variety on harvest index is shown in Table 7. The experiment revealed that there was no significant statistical difference between varieties regarding harvest index. $\mathrm{V}_{2}$ showed the maximum harvest index (55.85\%) over $\mathrm{V}_{1}(53.06 \%)$. The maximum harvest index obtained from PSC-121 $\left(\mathrm{V}_{2}\right)$ [14].

The experiment revealed that there was no significant statistical difference among weed control treatments irrespective of numerical difference (Table 8). $\mathrm{T}_{0}$ showed the maximum harvest index $(55.46 \%)$ and it was followed by $\mathrm{T}_{3}$ (55.36\%). The minimum harvest index was reported from $\mathrm{T}_{1}$ (52.64\%).

Interaction effect of variety and weed control treatments on harvest index is 
placed in Table 9. The experiment revealed that there was no significant statistical difference among weed control treatments irrespective of numerical difference. $\mathrm{V}_{2} \mathrm{~T}_{0}$ showed the maximum harvest index $(56.09 \%)$ and it was followed by $\mathrm{V}_{2} \mathrm{~T}_{3}(56.09 \%)$. The minimum harvest index was reported from $\mathrm{V}_{1} \mathrm{~T}_{1}(50.94 \%)$.

\section{Conclusion}

From the above findings it can be concluded that PSC-121 is the best performer regarding growth and yield attributes of white maize. Weed free $\left(\mathrm{T}_{3}\right)$ is the most suitable one to control weeds in white maize fields but almost in all cases $T_{2}$ was statistically similar to $\mathrm{T}_{3}$. Treatments $\mathrm{V}_{2} \mathrm{~T}_{3}$ and $\mathrm{V}_{1} \mathrm{~T}_{3}$ were the most effective combination offering the maximum growth and yield in white maize. On the other hand, in the consideration of weed tolerance capacity, the best interaction to be recommended is $\mathrm{V}_{1} \mathrm{~T}_{2}$.

\section{Acknowledgements}

The authors acknowledge the financial contribution of the Krishi Gobeshona Foundation (KGF), Farmgate, Dhaka, Bangladesh to carry out this research work.

\section{Conflicts of Interest}

The authors declare no conflicts of interest regarding the publication of this paper.

\section{References}

[1] Akbar, M.A., Siddique, M.A., Marma, M.S. and Ullah, J.M. (2016) Planting Arrangement, Population Density and Fertilizer Application Rate for White Maize Production in BandarbanValley. Agriculture, Forestry and Fisheries, 5, 215-224. https://doi.org/10.11648/j.aff.20160506.12

[2] Cassman, K.G., Grassini, P. and Van Wart, J. (2010) Crop Yield Potential, Yield Trends and Global Food Security in a Changing Climate. In: Rosenzweig, C., Hillel, D. (Eds.), Handbook of Climate Change and Agroecosystems. Imperial College Press, London, 37-51. https://doi.org/10.1142/9781848166561_0004

[3] Ray, D.K., Mueller, N.D., West, P.C. and Foley, J.A. (2013) Yield Trends Are Insufficient to Double Global Crop Production by 2050. PLoS ONE, 8, e66428.

https://doi.org/10.1371/journal.pone.0066428

[4] Timsina, J., Jat, M.L. and Majumdar, K. (2010) Rice-Maize Systems of South Asia: Current Status, Future Prospects and Research Priorities for Nutrient Management. Plant and Soil, 335, 65-82. https://doi.org/10.1007/s11104-010-0418-y

[5] Ali, M.Y., Waddington, S.R., Timsina, J., Hodson, D. and Dixon, J. (2010) Maize-Rice Cropping Systems in Bangladesh: Status and Research Needs. Journal of Agricultural Sciences and Technology, 3, 35-53.

[6] BBS (2016) Yearbook of Agricultural Statistics 2014. Ministry of Planning, Government of Bangladesh, Dhaka.

[7] Lee, E. and Tollenbar, M. (2007) Physiological Basis of Successful Breeding Strategies for Maize Grain Yield. Crop Science, 47, 202-215.

https://doi.org/10.2135/cropsci2007.04.0010IPBS 
[8] Macharia, C.N., Njeru, C.M., Ombakho, G.A. and Shiluli, M.S. (2010) Comparative Performance of Advanced Generations of Maize Hybrids with a Local Maize Variety: Agronomic and Financial Implications for Smallholder Farmers. Journal of Animaland Plant Sciences, 7, 801-809.

[9] Ullah, M.J., Islam, M.M., Fatema, K., Mahmud, M.S. and Rahman, J. (2017) Comparing Modern Varieties of White Maize with Land Races in Bangladesh: Phenotypic Traits and Plant Characters. Journal of Experimental Biosciences, 8, 27-40.

[10] Deewan, P., Mundra, S.L., Singh, D., Meena, M., Verma, R. and Sharma, N.K. (2017) Effect of Weed and Nutrient Management on Growth, Productivity and Protein Content of Quality Protein Maize (Zea mays L.). Journal of Pharmacognosy and Phytochemistry, 6, 271-274.

[11] Oerke, E.C. and Dehne, W.H. (2004) Safeguarding Production Losses in Major Crops and the Role of Crop Production. Crop Protection, 23, 275-285.

https://doi.org/10.1016/j.cropro.2003.10.001

[12] Chikoye, D., Manywong, V.M., Carsky, R.J., Gbehounou, G. and Ahanchede, A. (2002) Response of Speargrass (Imperata cylindrical) to Cover Crops Integrated With Hand Weeding and Chemical Control in Maize and Cassava. Crop Protection, 19, 481-497. https://doi.org/10.1016/S0261-2194(00)00044-2

[13] Adebooye, O.C., Ajadi, S.O. and Fagbohun, A.B. (2006) An Accurate Mathematical Formula for Estimating Plant Population in a Four Dimensional Field of Sole Crop. Journal of Agronomy, 5, 289-292. https://doi.org/10.3923/ja.2006.289.292

[14] Mannan, M.A. (2018) Varietal Performances of White Maize as Influenced by Different Level of Herbicides. Master's Thesis, Department of Agronomy, Sher-e-Bangla Agricultural University, Dhaka.

[15] Abdullahi, S., Ghosh, G. and Dawson, J. (2016) Effect of Different Weed Control Methods on Growth and Yield of Maize (Zea mays L.) under Rainfed Condition in Allahabad. Journal of Agriculture and Veterinary Sciences, 9, 44-47.

[16] Imoloame, E.O. and Omolaiye, J.O. (2017) Weed Infestation, Growth and Yield of Maize (Zea mays L.) as Influenced by Periods of Weed Interference. Advances in Crop Science and Technology, 5, 2.

[17] Kebede, M. and Anbasa, M. (2017) Efficacy of Pre-Emergence Herbicides for the Control of Major Weeds in Maize (Zea mays L.) at Bako, Western Oromia, Ethiopia. American Journal of Agriculture and Forestry, 5, 173-180.

https://doi.org/10.11648/j.ajaf.20170505.15 